The more distant localities did not, of course, view the same edge as those nearer, but one which must have been rather nearer them and lower down. Thus they are subject to a positive and a negative source of error, which cannot be well estimated, but which fortunately tend to neutralize each other.

The resulting height is unexpected, but the records agree so nearly as to leave little doubt of its substantial accuracy. Mr. Backhouse's measurements were made merely for altitude and an hour later, but the cloud-shift was so slight that it has been included. J. EDMUND ClaRk.

\section{A Dust Storm at Sea}

A FEW days ago, while returning to Tokio from the southern part of Japan, I joined the s.s. Yokshama Maru, which, whilst crossing from Shanghai to Nagasaki had passed through a curious dust storm. Small quantities of the dust were yet to be seen in sheltered corners of the vessel. The commander, Cap tain R. Swain, who gave me a specimen of the material, told me that on April 2, when about 95 miles west by south of Nagasaki (long. $128^{\circ} \mathrm{E}$., lat. $32^{\circ} 2 \mathrm{o}^{\prime} \mathrm{N}$.), at about $6 \mathrm{p}$. m. the sun appeared quite yellow. The atmosphere was moist, and rendered everything upon the deck of the ship quite damp. The precipitated moisture was yellowish, and as it dried it left an extremely fine powder. For two days previously the wind had been blowing west-south-west, or from China. Nothing was felt in the eyes, and if the ship had not been covered with yellow powder, the phenomenon would have been regarded as an ordinary but peculiarly coloured fog.

The yellow atmosphere was noticed during the afternoon of the 2nd. At midnight the wind changed to north-west-that is, from Corea. The probability, however, is that the material came from the loess plains of China. In Nagasaki, which is 390 miles from the coast of China, a yellow sun was noticed on the morning of the 2nd ; and during the day, whilst dust was being precipitated, the appearance of the atmosphere was compared to that of a London fog.

On April I there was a fall of dust in the neighbourhood of Nawa in Okinawa-ken, and on the 2nd dust fell in Gifu-the district where the recent great earthquake took place. The P. and O. s.s. Verona, which left Hong Kong on April I, experienced the same pheriomenon as the Yokohama Maru, the vessel being covered with a fine dust, which, when suspended in the atmosphere, gave rise to so much haze that land was not seen until reaching Nagasaki. On April 3 a yellow sun was seen in Yokohama, but I am not aware that any dust was observed. Roughly speaking, it therefore seems that on April 2, at a distance of from 200 to 400 miles from the coast of China, there was a cloud of dust which may have been over 1000 miles and possibly 2000 miles in length. Dr. B. Koto, who examined a specimen, tells me that the particles are chiefly felspar, but there is a little quartz and shreds of plants.

Tokio, April 23.

\section{Submerged Forest.}

DURING a recent visit to an East Lincolnshire seaside place, Mabelthorpe, the remains of a submerged forest were pointed out to me plainly visible at low water. On closer inspection, the stumps of fallen trees, firmly embedded in the clay from one to twenty inches above the surface could be traced along the low. water level. I should be much obliged if any reader could fix a date at which the forest was growing. Does it not prove a subsidence of land in the neighbourhood? M. H. M.

\section{Carnivorous Caterpillars.}

I sHould like to know if it is a known fact that some caterpillars are carnivorous, eating their own kind, and small ones of another kind? I have found on a lime-tree on our lawn, six caterpillars, two of which have done so.

One of them has (though there was plenty of food, as I had only taken it from the tree a few minutes) eaten one of its own kind about three-quarters its own size ; and later on in the day a small green looper (off the lime-tree), which was in the same box. A second has eaten two small loopers. The other three I only found to-day, and they are not as large as those which had eaten their fellows.

I cannot find a description of this caterpillar in "Das Buch der Schmetterlinge" (Lutz), which I use.

They are of a bright green, the colour of the young lime leaves, with a narrow white line down the back and along each side half-way down, and a broader one lower down. Between this and the narrow side-stripe are three very small black spots; between the back line and the narrow side-line, are two black spots, to each segment. Each spot has a white edge. On the first two segments the upper two spots are one under the other but on the rest are side by side. The three spots form an $\mathrm{L}$, with the two lower ones very near, or on the broad side-line.

They have eight prolegs, as well as the two suckers at the back. They appear very irritable, and swing their heads from side to side when touched, and apparently nip other caterpillars which dare to touch them in any way.

I may also mention that there are three very fine specimens of the Red Admiral (Vanessa Atalanta) in our garden to-day and yesterday.

Blackbrook, Bickley, Kent, May 29. Uliet N. Williams.

\section{THE HURRICANE IN MAURITIUS.}

$\mathrm{THE}$ devastation caused by the hurricane in Mauritius was so terrible that it was hardly to be expected the Observatory would be spared. We are glad to say, however, that it suffered no damage ; and all meteorologists will congratulate themselves that the well-known Director, Mr. Meldrum, was able without delay to prepare an account of the storm. The account is printed in the special overland edition of The Merchants and Planters Gazette, May II. We here reproduce it :--

$$
\text { "Saturday, April } 30 .
$$

"The hurricane which raged for a few hours yesterday, April 29, has in many respects been unprecedented in Mauritius.

"Never till now has the island been visited by a hurricane at any time between April I2 and December I. Hitherto the hurricane season of Mauritius has been supposed to begin on the latter and to end on the former day, and till yesterday there has been no exception to the rule.

"Nor was there any sign of danger till yesterday, when the barometer began to fall rapidly and the wind to increase to a heavy gale. The suddenness, rapidity, and extent of the changes which took place in a few hours are unparalleled in the annals of the colony.

" The following table will for the present suffice to convey some idea of the changes which took place in the barometric pressure and the direction and velocity of the wind from 9 a.m. on the $24^{\text {th }}$ to 9 p.m. on the 29 th :-

\begin{tabular}{|c|c|c|c|c|}
\hline \multirow[b]{2}{*}{$\begin{array}{l}\text { Day and } \\
\text { Hour. }\end{array}$} & \multicolumn{2}{|c|}{ Barometer. } & \multicolumn{2}{|c|}{ Wind. } \\
\hline & $\begin{array}{l}\text { Cor. and } \\
\text { reduced to } \\
\text { sea-level. }\end{array}$ & $\begin{array}{l}\text { Fall or Rise } \\
\text { per hour cor. } \\
\text { for var. }\end{array}$ & $\begin{array}{c}\text { Mean } \\
\text { Direction. }\end{array}$ & $\begin{array}{l}\text { Velocity in } \\
\text { miles per } \\
\text { hour. }\end{array}$ \\
\hline April 24 & Inches. & & & \\
\hline $\begin{array}{l}9 \text { a.m. } \\
\text { A pril } 27\end{array}$ & 30.059 & - & E.S.E. $\frac{1}{2}$ S. & 3 \\
\hline April 28 & $29^{\circ} 903$ & - & E. by S. & 15 \\
\hline 9 a.m. & 905 & - & N.E. by E. & 12 \\
\hline 4 p.m. & $\cdot 8 \mathrm{r} 6$ & -0.003 & N.E. by E. & 14 \\
\hline April 29 p.m. & $\cdot 850$ & -0.006 & N.E. & 12 \\
\hline 6 a.m. & 660 & -0.018 & N.E. by E. & 22.4 \\
\hline $8 \quad$, & 630 & -0.029 & N.E. $\frac{1}{2}$ E. & 347 \\
\hline $9 \quad$, & $\cdot 576$ & -0.063 & N.E. by E. & $35^{\circ} \mathrm{O}$ \\
\hline ro ,", & 480 & -0.094 & E.N.E. $\frac{1}{2}$ N. & $40^{\circ} \mathrm{O}$ \\
\hline II , & 338 & $-0.13 x$ & N.E. by E. & 520 \\
\hline Noon & .066 & -0.251 & N.E. $\frac{1}{2}$ E. & $68 \cdot 0$ \\
\hline I p.m. & 28.517 & -0.532 & N.E. $\frac{1}{2}$ E. & $96 \cdot 5$ \\
\hline 2 & 27.990 & -0.513 & & $560^{\circ}$ \\
\hline 3, & 28.034 & +0.048 & W.N.W. & $68 \cdot 0$ \\
\hline 4, & $\cdot 520$ & +0.483 & W.S.W. & $112 \%$ \\
\hline 5, & 29.059 & +0.529 & S.W. & 82.0 \\
\hline $9 "$ & 719 & +0.151 & S. Wrd. & 260 \\
\hline
\end{tabular}
No. I I 80 , vol. 46 ] 
"In the above table the fall or rise in the barometric pressure is corrected for the daily variation, and from 9 a.m. on the 24 th to 9 a.m. on the 29 th the mean hourly velocities of the wind are given, whereas from Io a.m. to 5 p.m. on the 29 th the rates of the velocity per hour are given as obtained from observations taken during intervals of two to five minutes.

"It will be seen that at 2 p.m. on the 29 th the barometer was at $27^{\circ} 990$ inches; that from noon to 2 p.m. it fell $\mathrm{I}^{\circ} \mathrm{O} 45$ inch; that from 3 to 5 p.m. it rose $\mathrm{I}^{\circ} \mathrm{OI} 2$ inch; and that from 5 to 9 p.m. it rose 660 inch. The absolutely lowest pressure was $27^{\circ}$. $^{\circ}$ inches at 2.30 p.m., which is the lowest on record in Mauritus.

"From 9 a.m. on the 28 th to I p.m. on the 29 th the mean direction of the wind did not vary much, but it occasionally showed a tendency to veer towards north, being at times from north-east by north to north-northeast. Between I and 2 p.m. it on the whole veered to north, and between 2 and 3 p.m. to west-north-west, oscillating considerably, and soon after settling down at west-south-west.

"After I I a.m. the velocity of the wind increased much, being at I p.m. at the rate of 96.5 miles an hour, and at I.2O at the rate of 104 miles. But from I.25 to 2.30 p.m. there was a lull, the velocity decreasing to the rate of 43 miles an hour at 2.33 p.m. It then besan to increase again, and at 3.47 p.m. was at the rate of $\mathrm{I} 2 \mathrm{I} \cdot 2$ miles per hour, but it soon began to abate, being at the rate of 72 miles at 5.20 p.m., 60 miles at 6 p.m., 47 miles at 7 p.m. and 26 miles at 9 p.m. By this time the weather was fine, the sky partially clear, and here and there stars shining brightly.

"Seeing that from 9 a.m. on the 24 th to 9 a.m. on the 27 th the barometer had fallen from 30.059 to $29^{\circ} 903$ inches, and that the wind, though light, had veered from east-south-east half south to east by south, a note was sent to the newspapers on the latter day, stating that there was heavy weather to the northward, and that it had existed since the 24th ; which, as usual in such circumstances, meant that there were indications of a cyclone away to the northward and that it was travelling from north-eastward to south-westward.

"But the wind having by 9 a.m. on the 28 th reached north-east by east, and the barometer being higher on the 27 th at the same hour, there was no apprehension; and in the afternoon of the 28 th, the wind being still moderate from north-eastward, and the barometer falling at the rate of only 0.003 inch per hour, it was announced that there was no fear.

"As already stated, it was only on the 29th that the conditions became unfavourable, and at 9.40 a.m. a telegram was despatched announcing that the barometer was falling at an accelerating rate.

"Other telegrams, despatched at II a.m., announced that the velocity of the wind was at the rate of 52 miles an hour in the squalls, and that probably it would not exceed 56 miles an hour. Soon afterwards the telegraph wires were broken, and all communication ceased.

"The barometer continuing to fall at an accelerating rate, and the mean direction of the wind being nearly constant, it was inferred that the centre of the depression would, contrary to long experience (the wind being from north-east) pass over the island, and that the wind would then come from nearly the opposite direction.

"The centre, however did not pass over the Observatory, but over a point about six miles to the westward of it, and apparently from that point it travelled across the island on an east-south-easterly course.

"As a rule, when the wind is from north-eastward, there is scarcely any danger of a hurricane in Mauritius. All our great hurricanes have commenced, not with a north-easterly, but with a south-easterly wind; and this is why, when the wind was from north-east by east at II a.m. yesterday, and the barometer at $29.33^{8}$, it was No. I I 80 , VOL. 46 ] considered probable that the velocity of the wind would not exceed 56 miles an hour. On February 12 last, the barometer fell to 29.325 , and the greatest velocity of the wind was $47^{\circ} 5$ miles per hour from north-east, the barometer soon afterwards rising and the wind decreasing.

" There are, apparently, only two ways of, in a measure, accounting for the passage of the centre of a hurricane over the island yesterday from west-north-westward to east south-eastward. Firstly, the cyclone which had been travelling to the northward and north-westward of the island on a south-westerly course, from the 24 th to the 27 th, recurved to the southward and south-eastward; or secondly, a small secondary cyclone, which was generated in the south-east quadrant of the larger cyclone, travelled to the east-south-eastward, and bore down on Mauritius. The latter is perhaps the more probable hypothesis ; for the small but violent hurricane of yesterday, with respect to its extent, duration, \&c., exhibited the characteristics of a local atmospheric disturbance.

"On the night of the 27 th and morning of the 28 th there was a great deal of thunder and lightning, and also frequent lightning during the night of the $28 \mathrm{th}$. But the hurricanes of Mauritius are seldom, if ever, immediately preceded by thunder and lightning.

"It may be stated, also, that from the $25^{\text {th }}$ to the 29 th there were from five to six groups of sun-spots, indicating a considerable increase of solar activity; and that from the 25 th to the 28 th there were large magnetic disturbances, the portion of the sun's disk on which there was a very large group of spots on February i2 being again on or near the sun's central meridian.

"C. Meldrum."

\section{PROFESSOR JAMES THOMSON}

PROF. JAMES THOMSON, who died on May 8, after a few days' illness, the result of a chill, was born in Belfast in I822. He was the son of James Thomson, who was then Lecturer on, and afterwards Professor of, Mathematics in Belfast, and subsequently became Professor of Mathematics in Glasgow University. The father was a highly successful teacher and original investigator in mathematics, and was the author of many important school books. One of these books was, thirty years ago, still the recognized text-book on arithmetic in Ireland, and in all probability still retains its position. It was referred to by its very well-known title the "Thomson," by Prof. Tyndall in his British Association Address in I 874. We do not need the assurances of contemporaries, which are plentiful, that the two boys, James and William Thomson (now Lord Kelvin), made brilliant progress in their father's subject, and exhibited, even in early days, that combination of inventive genius and painstaking effort for accuracy, which have been their great characteristics since. James took his M.A. degree at Glasgow, served an apprenticeship under Sir William Fairbairn, and practised in Belfast as an engineer. $\mathrm{He}$ held the appointments of engineer to the Belfast Water Commissioners and to the Lagan Canal Navigation Works. In 1857 he became Professor of Civil Engineering in Queen's College, Belfast, and his Belfast pupils are to be found occupying high positions in every part of the world. He succeeded Rankine in Glasgow in 1872, and resigned the Professorship at Glasgow in I 889 because his eyesight was failing. He became a Fellow of the Royal Society in 1877 . He received the honorary degrees of D.Sc. from the Queen's University of Ireland, and of LL.D. from Glasgow and from Dublin. In 1853 he married the only daughter of the late $\mathrm{Mr}$. William John Hancock, J.P., of Lurgan, Co. Armagh, and it is a pathetic circumstance connected with his death, that she and one of his daughters survived him only a few days. He leaves a son and another daughter. 